Jurnal Ners Indonesia, Vol. 9, No. 1, September 2018

\title{
TINGKAT PENGETAHUAN DAN SIKAP WANITA PASANGAN USIA SUBUR (PUS) TERHADAP IMUNISASI VAKSIN HPV
}

\author{
Sukma Rahmayanti ${ }^{1}$, Asfeni $^{2}$, Sekani Niriyah ${ }^{3}$ \\ ${ }^{1}$ PSIK STIKes Hang Tuah Pekanbaru, ${ }^{2}$ RSUD Arifin Achmad Pekanbaru, ${ }^{3}$ PSIK STIKes Hang Tuah Pekanbaru \\ Kode Pos 28000 Indonesia \\ Telepon 085376867030 e-mail: sukmarahmayanti96@yahoo.com
}

\begin{abstract}
Abstrak
Kesehatan reproduksi adalah kemampuan seseorang dalam berproduksi, dapat menghasilkan anak yang sehat, serta aman dalam proses hubungan seksual. Penyakit yang sering menyerang organ reproduksi wanita salah satunya kanker serviks. Kanker serviks merupakan penyakit penyebab kematian biasanya menyerang wanita pada pasangan usia subur. Penelitian ini bertujuan untuk mengetahui hubungan tingkat pengetahuan dan sikap wanita pasangan usia subur terhadap imunisasi vaksin HPV di wilayah kerja Puskesmas Rawat Inap Sidomulyo Pekanbaru. Jenis penelitian kuantitatif dengan desain cross-sectional dan teknik sampling yang digunakan adalah Stratified Random Sampling kepada 100 responden. Hasil penelitian didapatkan mayoritas wanita PUS memiliki tingkat pengetahuan cukup sebanyak 39 responden $(39,0 \%)$ dan sikap negatif sebanyak 51 responden $(51,0 \%)$. Hasil uji chi square terdapatnya hubungan antara tingkat pengetahuan terhadap imunisasi vaksin HPV dengan $p$ value $0,024(<0,05)$ dan terdapat hubungan antara sikap terhadap imunisasi vaksin HPV dengan $\mathrm{p}$ value 0,009 $(<0,05)$. Disarankan kepada tenaga kesehatan untuk lebih aktif dalam memberikan informasi tentang pencegahan kanker serviks dengan imunisasi vaksin HPV berupa penyuluhan dan pemberian leaflet untuk dibaca dan dibawa pulang, sehingga wanita PUS dapat memperhatikan kesehatan reproduksi yang akan berdampak terhadap penurunan angka kesakitan dan kematian akibat kanker serviks.
\end{abstract}

Kata Kunci: Imunisasi Vaksin HPV, Sikap, Tingkat Pengetahuan, Wanita Pasangan Usia Subur

\begin{abstract}
Reproductive health is a person's ability to produce, can produce healthy children, and is safe in the process of sexual intercourse. Diseases that often attack the female reproductive organs include cervical cancer. Cervical cancer is a disease that causes death usually attacks women in couples of childbearing age. This study aims to determine the relationship between the level of knowledge and attitudes of women of reproductive age to immunization against HPV vaccines in the work area of the Sidomulyo Inpatient Health Center in Pekanbaru. The type of quantitative research isdesign cross-sectional and the sampling technique used is Stratified Random sampling to 100 respondents. The results showed that the majority of PUS women had a sufficient level of knowledge as many as 39 respondents (39.0\%) and negative attitudes were 51 respondents (51.0\%). Thetest results chi squareshowed a correlation between the level of knowledge of HPV vaccine immunization and $p$ value $0.024(<0.05)$ and there was a relationship between attitudes toward HPV vaccine immunization and $p$ value 0.009 (<0.05). It is recommended that health workers be more active in providing information about prevention of cervical cancer by immunizing the HPV vaccine in the form of counseling and giving leaflets to read and take home, so that female couples aged fertile can pay attention to reproductive health which will have an impact on decreasing morbidity and mortality from cervical cancer.
\end{abstract}

Keywords: HPV Vaccine Immunization, Attitude, Level of Knowledge, Female Couples Aged of Fertile

\section{PENDAHULUAN}

Penyakit serius yang sering menyerang organ reproduksi pada wanita adalah kanker serviks. Penyakit ini terhitung dengan jumlah penderitanya yang semakin meningkat beberapa tahun belakangan, dari seluruh penderita kanker 
Sukma Rahmayanti ${ }^{1}$, Asfeni ${ }^{2}$, Sekani Niriyah ${ }^{3}$,Tingkat Pengetahuan Dan Sikap Wanita Pasangan Usia Subur (Pus) Terhadap Imunisasi Vaksin Hpv yang ada di Negara Indonesia, sepertiganya adalah penderita kanker serviks (Tilong, 2012).

Data yang didapat dari GLOBOCAN (2012), tercatat sebanyak 528.000 kasus baru kanker serviks. Negara didunia yang memiliki angka tertinggi kasus kanker serviks adalah Afrika Timur (42,7 per 100.000), sedangkan angka terendah adalah Asia Barat (4,4 per 100.000). Tercatat sekitar 266.000 kematian wanita diseluruh dunia diakibatkan oleh kanker serviks.

Berdasarkan data dari Kemenkes RI (2015), penyakit kanker serviks adalah prevalensi tertinggi di Indonesia. Tercatat angka kejadian kanker serviks sebesar $0,8 \%$ pada tahun 2013. Provinsi yang memiliki angka kejadian tertinggi kanker serviks di Indonesia adalah provinsi D.I. Yogyakarta, Maluku Utara dan Kepulauan Riau dengan prevalensi angka kejadian sebesar 1,5\%, sedangkan Provinsi Riau berada pada urutan ke 13 dengan angka kejadian sebesar 0,3\% atau sebanyak 894 jiwa.

Kota Pekanbaru tercatat sebanyak 54 kasus kanker serviks pada tahun 2016 dan terjadi peningkatan pada tahun 2017 yaitu sebanyak 425 kasus kanker serviks. Angka kejadian kanker seviks pada bulan Januari hingga Februari tahun 2018 tercatat sebanyak 100 kasus kanker serviks (data Medical Record RSUD Arifin Achmad, 2018).

Menurut IARC (International Agency for Research on Cancer) (2017), angka kejadian kanker serviks agar tidak terus meningkat dapat

dicegah dengan melakukan pemberian vaksinasi terhadap wanita. Vaksinasi pencegahan memerangi kanker serviks, namun dibanyak Negara, vaksinasi HPV masih belum terealisirkan. Kepala Seksi Deteksi Dini di IARC Dr. Rolando Herrero, menjelaskan vaksinasi HPV sangat penting dilakukan untuk mengurangi epidemiologi yang terjadi diseluruh dunia. Sejak di tahun 2006, sebanyak 75 negara telah memperkenalkan vaksinasi HPV untuk melindungi wanita dari kanker serviks (Kartikawati, 2013).

Menurut Dr Andrijono, SpOG mengatakan bahwa vaksin HPV dapat diberikan pada wanita yang belum aktif secara seksual maupun yang sudah aktif secara seksual, hanya saja wanita yang sudah aktif secara seksual harus negatif dari hasil skrining (Detik Health-Sukmasari, 2018).

Berdasarkan latar belakang diatas peneliti tertarik melakukan penelitian tentang "Hubungan Tingkat Pengetahuan dan Sikap Wanita Pasangan Usia Subur (PUS) Terhadap Imunisasi Vaksin HPV di Wilayah Kerja Puskesmas Rawat Inap Sidomulyo Pekanbaru, Riau”

\section{METODE PENELITIAN}

Jenis penelitian yang digunakan adalah kuantitatif dengan desain cross sectional. Populasinya adalah wanita pasangan usia subur (PUS) dengan sampel 100 responden. Pengambilan sampel menggunakan teknik 
Jurnal Ners Indonesia, Vol. 9, No. 1, September 2018

Stratified Random Sampling. Alat pengumpulan data menggunakan kuesioner dan analisa data dilakukan secara univariat dan bivariat.

\section{HASIL PENELITIAN}

\section{Analisa Univariat}

1. Karakteristik Responden

\begin{tabular}{|c|c|c|}
\hline Karakteristik Responden & $\mathbf{F}$ & $\%$ \\
\hline \multicolumn{3}{|l|}{ Usia } \\
\hline $17-25$ tahun & 5 & 5,0 \\
\hline $26-35$ tahun & 57 & 57,0 \\
\hline $36-45$ tahun & 38 & 38,0 \\
\hline Jumlah & 100 & $\overline{100,0}$ \\
\hline \multicolumn{3}{|l|}{ Lama Menikah } \\
\hline 2 tahun & 1 & 1,0 \\
\hline 3 tahun & 2 & 2,0 \\
\hline 4 tahun & 12 & 12,0 \\
\hline 5 tahun & 22 & 22,0 \\
\hline 6 tahun & 11 & 11,0 \\
\hline 7 tahun & 12 & 12,0 \\
\hline 8 tahun & 1 & 1,0 \\
\hline 9 tahun & 1 & 1,0 \\
\hline 10 tahun & 4 & 4,0 \\
\hline 11 tahun & 2 & 2,0 \\
\hline 12 tahun & 7 & 7,0 \\
\hline 13 tahun & 5 & 5,0 \\
\hline 14 tahun & 3 & 3,0 \\
\hline 15 tahun & 3 & 3,0 \\
\hline 16 tahun & 3 & 3,0 \\
\hline 17 tahun & 2 & 2,0 \\
\hline 18 tahun & 3 & 3,0 \\
\hline 19 tahun & 4 & 4,0 \\
\hline 20 tahun & 2 & 2,0 \\
\hline \multicolumn{3}{|l|}{ Jumlah Anak } \\
\hline 1 Orang & 3 & 3,0 \\
\hline 2 Orang & 42 & 42,0 \\
\hline 3 Orang & 51 & 51,0 \\
\hline 4 Orang & 4 & 4,0 \\
\hline \multicolumn{3}{|l|}{ Pendidikan Terakhir } \\
\hline SD & 2 & 2,0 \\
\hline SMP & 31 & 31,0 \\
\hline SMA/SMK & 49 & 49,0 \\
\hline Perguruan Tinggi & 18 & 18,0 \\
\hline \multicolumn{3}{|l|}{ Pekerjaan } \\
\hline Bekerja & 13 & 13,0 \\
\hline Tidak Bekerja & 87 & 87,0 \\
\hline Jumlah & 100 & 100,0 \\
\hline
\end{tabular}

Mayoritas berada pada kelompok dewasa awal dengan rentang umur 26-35 tahun sebanyak 57 responden $(57,0 \%)$, usia pernikahan paling banyak selama 5 tahun yaitu 22 responden $(22,0 \%)$, responden memiliki 3 anak sebanyak 51 responden $(51,0 \%)$, mayoritas berpendidikan SMA/SMK sebanyak 49 responden $(49,0 \%)$, dan mayoritas tidak bekerja sebanyak 87 responden $(87,0 \%)$.

2. Tingkat Pengetahuan

\begin{tabular}{ccc}
\hline Tingkat Pengetahuan & F & \% \\
\hline Baik & 27 & 27,0 \\
Cukup & 39 & 39,0 \\
Kurang & 34 & 34,0 \\
\hline Jumlah & $\mathbf{1 0 0}$ & $\mathbf{1 0 0 , 0}$ \\
\hline
\end{tabular}

Mayoritas memiliki tingkat pengetahuan cukup, yaitu sebanyak 39 responden $(39,0 \%)$.

3. Sikap

\begin{tabular}{ccc}
\hline Sikap & F & \% \\
\hline Positif & 49 & 49,0 \\
Negatif & 51 & 51,0 \\
\hline Jumlah & $\mathbf{1 0 0}$ & $\mathbf{1 0 0 , 0}$ \\
\hline
\end{tabular}

Mayoritas memiliki sikap negatif, yaitu sebanyak 51 responden $(51,0 \%)$.

4. Variabel Imunisasi Vaksin HPV

\begin{tabular}{ccc}
\hline $\begin{array}{c}\text { Keinginan } \\
\text { Melakukan Imunisasi } \\
\text { Vaksin HPV }\end{array}$ & F & \% \\
\hline Ya & 48 & 48,0 \\
Tidak & 52 & 52,0 \\
\hline Jumlah & $\mathbf{1 0 0}$ & $\mathbf{1 0 0 , 0}$ \\
\hline \multicolumn{3}{c}{ Mayoritas tidak berkeinginan melakukan } \\
imunisasi vaksin HPV, yaitu sebanyak 52 \\
responden $(52,0 \%)$.
\end{tabular}


Sukma Rahmayanti ${ }^{1}$, Asfeni $^{2}$, Sekani Niriyah ${ }^{3}$,Tingkat Pengetahuan Dan Sikap Wanita Pasangan Usia Subur (Pus) Terhadap Imunisasi Vaksin Hpv

\section{Analisa Bivariat}

1. Tingkat Pengetahuan dan Keinginan Melakukan Imunisasi Vaksin HPV

\begin{tabular}{|c|c|c|c|c|c|c|c|}
\hline \multirow{4}{*}{$\begin{array}{c}\text { Tingkat } \\
\text { Pengetahuan }\end{array}$} & \multicolumn{4}{|c|}{ Keinginan } & \multirow{3}{*}{\multicolumn{2}{|c|}{ Total }} & \multirow{3}{*}{$P$} \\
\hline & \multicolumn{4}{|c|}{$\begin{array}{l}\text { Melakukan Imunisasi } \\
\text { Vaksin HPV }\end{array}$} & & & \\
\hline & \multicolumn{2}{|c|}{$\mathrm{Ya}$} & \multicolumn{2}{|c|}{ Tidak } & & & \\
\hline & $\mathrm{N}$ & $\%$ & $\mathrm{~N}$ & $\%$ & $\mathrm{~N}$ & $\%$ & value \\
\hline Baik & 19 & 19,0 & 8 & 8,0 & 27 & 27,0 & 0,024 \\
\hline Cukup & 16 & 16,0 & 23 & 23,0 & 39 & 39,0 & \\
\hline Kurang & 13 & 13,0 & 21 & 21,0 & 34 & 34,0 & \\
\hline Jumlah & 48 & 48,0 & 52 & 52,0 & 100 & 100,0 & \\
\hline
\end{tabular}

Dari 100 responden, yang berpengetahuan baik 27 responden $(27,0 \%)$, berkeinginan melakukan imunisasi vaksin HPV 19 responden $(19,0 \%)$, yang tidak berkeinginan 8 responden $(8,0 \%)$. Responden yang berpengetahuan cukup 39 responden $(39,0 \%), 16$ responden $(16,0 \%)$ memiliki keinginan melakukan imunisasi vaksin HPV, yang tidak berkeinginan 23 responden $(23,0 \%)$. Sedangkan, responden berpengetahuan kurang 34 responden $(34,0 \%)$, berkeinginan melakukan imunisasi vaksin HPV 13 responden $(13,0 \%)$, yang tidak berkeinginan 21 responden $(21,0 \%)$. Hasil uji statistik diperoleh $p$ value $0,024<0,05$ yang artinya terdapat hubungan tingkat pengetahuan terhadap imunisasi vaksin HPV dan Ho ditolak.
2. Sikap dan Keinginan Melakukan Imunisasi Vaksin HPV

\begin{tabular}{|c|c|c|c|c|c|c|c|}
\hline \multirow{3}{*}{ Sikap } & & $\begin{array}{l}\text { Kein } \\
\text { akuka } \\
\text { Valss }\end{array}$ & $\begin{array}{l}\text { ginan } \\
\text { Imu } \\
\text { HPP }\end{array}$ & nisasi & \multirow{2}{*}{\multicolumn{2}{|c|}{ Total }} & \multirow{3}{*}{$\begin{array}{c}P \\
\text { vall } \\
0,0\end{array}$} \\
\hline & \multicolumn{2}{|c|}{$\overline{\mathrm{Ya}}$} & \multicolumn{2}{|c|}{ Tidak } & & & \\
\hline & $\mathrm{N}$ & $\%$ & $\mathrm{~N}$ & $\%$ & $\mathrm{~N}$ & $\%$ & \\
\hline Positif & 30 & 30,0 & 19 & 19,0 & 49 & 49,0 & \\
\hline Negatif & 18 & 18,0 & 33 & 33,0 & 51 & 51,0 & \\
\hline Jumlah & 48 & 48,0 & 52 & 52,0 & 100 & 100,0 & \\
\hline
\end{tabular}

Dari 100 responden, 49 responden $(49,0 \%)$ memiliki sikap positif, berkeinginan melakukan imunisasi vaksin HPV 30 responden (30,0\%), yang tidak berkeinginan 19 responden $(19,0 \%)$. Sedangkan, yang memiliki sikap negatif 51 responden $(51,0 \%), 18$ responden $(18,0 \%)$ berkeinginan melakukan imunisasi vaksin HPV, tidak berkeinginan sebanyak 33 responden $(33,0 \%)$. Hasil uji statistik diperoleh $p$ value $0,009<0,05$ yang artinya terdapat hubungan yang signifikan antara sikap terhadap imunisasi vaksin HPV dan Ho ditolak.

\section{PEMBAHASAN}

\section{Umur}

Mayoritas responden berada pada kelompok umur dewasa awal yaitu 26-35 tahun yaitu sebanyak 57 responden. Kanker serviks dulunya diderita oleh wanita berumur $\geq 40$ tahun, namun juga dialami oleh wanita muda. Ini terjadi bukan masalah hormon tetapi akibat ketidakmampuan wanita menjaga kebersihan dan kesehatan organ reproduksinya dan kanker 
Jurnal Ners Indonesia, Vol. 9, No. 1, September 2018

serviks muncul apabila seorang wanita tersebut tidak menjaga gaya hidupnya (Savitri, 2015).

Menurut asumsi peneliti, responden didalam penelitian ini berada pada rentang usia subur dan berisiko terkena kanker serviks, sehingga perlu adanya kesadaran diri dan kematangan berfikir untuk melakukan upaya pencegahan kanker serviks terutama dengan imunisasi vaksin HPV.

\section{Lama Menikah}

Hasil penelitian menggambarkan bahwa sebagian besar responden telah menikah 5 tahun sebanyak $22,0 \%$.

Belum ada penelitian yang menyatakan bahwa ada kaitan antara lama menikah dengan kejadian kanker serviks, akan tetapi perilaku dan aktifitas seksual berkaitan erat. Sebagai contoh, seseorang yang melakukan hubungan seksual $\leq$ 20 tahun merupakan faktor risiko lebih tinggi terjadinya kanker serviks, karena organ reproduksi wanita belum memiliki tingkat kematangan yang sesuai. Usia yang dianggap paling optimal terhadap proses reproduksi pada wanita adalah 20-35 tahun (Savitri, 2015).

\section{Jumlah Anak}

Mayoritas responden memiliki 3 orang anak, yaitu sebanyak 51 responden. Kelahiran yang optimal adalah kelahiran sampai 3 kali, perubahan hormonal wanita selama kehamilan, membuat wanita lebih mudah terpapar infeksi karena memiliki imunitas lebih rendah, sehingga memudahkan masuknya virus HPV dalam tubuh yang berujung pada pertumbuhan kanker (Savitri, 2015).

Menurut asumsi peneliti, janis yang sering melewati serviks akan mengalami luka lecet atau dapat terjadinya trauma, dengan adanya trauma dan luka tersebut menjadi sumber infeksi hingga dapat menyebabkan terjadi kanker serviks. Oleh karena itu, perlu adanya konsultasi, pertimbangan dan pemikiran yang matang agar wanita PUS tetap produktif tetapi sehat dan terbebas dari kanker serviks.

\section{Pendidikan Terakhir}

Mayoritas responden berpendidikan sampai SMA/SMK yaitu sebanyak 49,0\%. Pendidikan memiliki hubungan erat dengan pengetahuan, dengan pendidikan tinggi maka semakin luas pengetahuan seseorang. Peningkatan pengetahuan tidak hanya diperoleh melalui pendidikan formal, tetapi dapat diperoleh melalui pendidikan non-formal (Wawan \& Dewi, 2011).

Peneliti berasumsi, latar belakang pendidikan SMA/SMK membuat responden tidak banyak tahu tentang imunisasi vaksin HPV. Pendidikan yang tinggi menjadikan pengetahuan seorang wanita menjadi luas, membangkitkan kepercayaan diri serta dapat mempertimbangkan hal baik dan hal buruk terkait kesehatan reproduksi terutama agar terhindar dari kanker serviks.

\section{Pekerjaan}

Mayoritas responden tidak bekerja yaitu sebanyak $87,0 \%$. Berbeda dengan penelitian 
Sukma Rahmayanti ${ }^{1}$, Asfeni ${ }^{2}$, Sekani Niriyah ${ }^{3}$,Tingkat Pengetahuan Dan Sikap Wanita Pasangan Usia Subur (Pus) Terhadap Imunisasi Vaksin Hpv yang dilakukan oleh T. C. Pamaruntuan, Grace D. Kandou. Billy J. Kepel (2017), terhadap 201 responden, yang berpengetahuan kurang sebanyak 121 responden, dan mayoritas respondennya bekerja yaitu sebanyak 121 responden.

Menurut asumsi peneliti, wanita yang bekerja dapat bertukar pikiran dengan sesama rekan kerja dan memiliki wawasan yang luas. Tetapi, wanita yang tidak bekerja justru memiliki banyak waktu luang untuk mencari informasi melalui gadget dengan mengakses internet.

\section{Tingkat Pengetahuan}

Mayoritas responden memiliki tingkat pengetahuan cukup yaitu sebanyak 39,0\% . Sesuai dengan teori yaitu pendidikan menuntut manusia untuk berbuat dan mengisi kehidupannya dalam mencapai suatu keselamatan dan kebahagiaan, oleh karena itu dengan pendidikan dapat memeliki pengetahuan hingga dapat menentukan tindakan dan perilaku selanjutnya. Pendidikan diperlukan seseorang untuk mendapatkan sebuah informasi seputar kesehatan yang dapat meningkatkan kualitas hidup seseorang (Priyoto, 2014).

\section{Sikap}

Sebanyak 100 responden, mayoritas memiliki sikap negatif yaitu berjumlah $51,0 \%$. Seperti yang dijelaskan pada teori bahwa sikap terdiri pada evaluasi seseorang terhadap berbagai aspek, dapat memunculkan rasa suka ataupun tidak terhadap objek, respon positif 
didapat dan sulitnya menjangkau harga imunisasi vaksin HPV.

\section{Tingkat Pengetahuan Terhadap Imunisasi Vaksin HPV}

Hasil penelitian terdapat hubungan antara tingkat pengetahuan terhadap imunisasi vaksin HPV $p$ value $=0,024<0,05$.

Seperti pada teori menurut Roger tahun 1974 bahwa pengetahuan adalah sesuatu hal penting terbentuknya tindakan seseorang, yang terjadi melewati proses berurutan seperti hadirnya kesadaran. Adanya ketertarikan, menimbang-nimbang manfaat yang didapat, mulai mencoba, hingga seseorang tersebut telah berperilaku sesuai dengan pengetahuan, kesadaran dan sikap terhadap stimulus yang diberikan (Notoatmodjo, 2011).

Sejalan dengan penelitian Mariane Dethan, Ni Luh Putu Suariyani (2017), terhadap 154 responden, terdapat hubungan yang signifikan antara pengetahuan dengan sikap responden terhadap vaksin HPV. Hasil penelitian tersebut menunjukkan sebanyak $50 \%$ memiliki tingkat pengetahuan cukup. sebanyak $71,43 \%$ responden tidak setuju jika melakukan vaksinasi HPV memerlukan biaya yang mahal dan sebanyak $76,62 \%$ responden masih bergantung pada persetujuan orang tua untuk melakukan vaksinasi.

Menurut asumsi peneliti, jika semakin banyak wanita PUS mendapatkan informasi tentang imunisasi vaksin HPV maka akan semakin baik juga bentuk perilaku dalam pencegahan kanker serviks, tetapi sebaliknya jika wanita PUS tidak memahami dengan baik tentang imunisasi vaksin HPV, maka akan menunjukkan perilaku tidak berminat melakukan pencegahan kanker serviks dengan imunisasi vaksin HPV.

\section{Sikap Terhadap Imunisasi Vaksin HPV}

Hasil penelitian hubungan antara sikap dengan imunisasi vaksin HPV ( $p$ value $=0,009$ $<0,05)$.

Sejalan dengan Amelia L. Nahak, Roni Yuliwar, Warsono (2018), terhadap 35 responden, terdapat hubungan pengetahuan ibu tentang kanker serviks dengan sikap mengikuti imunisasi vaksin HPV ( $p$ value $=0,029<0,05$ ). Hasil penelitian menunjukkan sebagian besar responden berpengetahuan baik dan memiliki sikap positif. Hal ini karena disebabkan oleh adanya kesadaran ibu-ibu untuk melakukan upaya pencegahan kanker serviks dan kesadaran ini timbul dari pengetahuan dan pemahaman yang baik

Menurut asumsi peneliti, mayoritas responden yang memiliki pengetahuan cukup, memperoleh informasi tidak maksimal, tidak adanya faktor pendorong dari pembentukan sikap yang menyebabkan sikap responden menjadi negatif, yang nantinya akan berdampak pada bentuk nyata suatu tindakan pencegahan kanker serviks dengan imunisasi vaksin HPV. 
Sukma Rahmayanti ${ }^{1}$, Asfeni ${ }^{2}$, Sekani Niriyah ${ }^{3}$,Tingkat Pengetahuan Dan Sikap Wanita Pasangan Usia Subur (Pus) Terhadap Imunisasi Vaksin Hpv

\section{SIMPULAN}

Wanita Pasangan Usia Subur (PUS) di Wilayah Kerja Puskesmas Rawat Inap Sidomulyo memiliki tingkat pengetahuan cukup dengan mayoritas memiliki sikap negatif dan sebagian besar tidak berkeinginan melakukan imunisasi vaksin HPV. Hasil uji statistik didapatkan terdapat hubungan yang signifikan antara tingkat pengetahuan dan sikap wanita pasangan usia subur (PUS) terhadap imunisasi vaksin HPV.

\section{DAFTAR PUSTAKA}

Amelia L. Nahak, Roni Yuliwar, Warsono, P. (2018). Hubungan pengetahuan ibu tentang kanker serviks dengan sikap untuk mengikuti imunisasi Human Papilloma Virus (HPV) di Kelurahan Tlogomas Kecamatan Lowokwaru Kota Malang. Nursing News, 3 No. 1, 164-174.

Detik Health-Sukmasari, R. N. (2018). Bagaimana efektivitas vaksin HPV untuk wanita di atas 45 Tahun?, 2-5. Retrieved from https://health.detik.com/beritadetikhealth/d-3471888/bagaimanaefektivitas-vaksin-hpv-untuk-wanita-diatas-45-tahun

GLOBOCAN. (2012). Cervical Cancer Estimated Incidence, Mortality and Prevalence Worldwide in 2012, 2-5. Retrieved from http://globocan.iarc.fr/old/FactSheets/canc ers/cervix-new.asp

IARC (International Agency for Research on Cancer). (2017). MEDIA CENTRE IARC NEWS World Cancer Day 2017, 25. Retrieved from http://www.iarc.fr/en/mediacentre/iarcnews/2017/wcd2017.php

Kartikawati, C. E. (2013). Awas!!! Bahaya kanker payudara \& kanker serviks. Bandung: Buku Baru.
Kementerian Kesehatan RI (Kemenkes RI). (2015). Pusat data dan informasi: situasi penyakit kanker. Retrieved from jakarta: Kemenkes RI

Mariane Dethan, Ni Luh Putu Suariyani, C. (2017). Pengetahuan dan sikap tentang perilaku vaksinasi HPV pada siswi SMA Swasta. Jurnal MKMI, 13 No., 167-175.

Notoatmodjo, S. (2011). Kesehatan masyarakat ilmu \& seni. Jakarta: Rineka Cipta.

Priyoto. (2014). Teori sikap \& perilaku dalam kesehatan dilengkapi contoh kuesioner. Yogyakarta: Nuha Medika.

RSUD Arifin Achmad, R. M. (2018). Angka kejadian kanker serviks di RSUD Arifin Achmad dari tahun 2016-2018. Retrieved from Pekanbaru

Savitri, A. dkk. (2015). Kupas tuntas kanker payudara, leher rahim, dan rahim. Yogyakarta: Pustaka Baru Press.

Sulistiowati, Anna Maria Sirait, E. (2014). Pengetahuan tentang faktor resiko, perilaku dan deteksi dini kanker serviks dengan Inspeksi Visual Asam Asetat (IVA) pada wanita di Kecamatan Bogor Tengah, Kota Bogor. Bul. Penelit. Kesehat, 42 no 3, 193-202.

T. C. Pamaruntuan, Grace D. Kandou. Billy J. Kepel, A. (2017). Faktor-faktor yang berhubungan dengan tindakan wanita usia reproduktif untuk melakukan Inspeksi Visual dengan Asam Asetat di Kelurahan Kinilow Kecamatan Tomohon Utara. Jurnal Ikmas, 2, No. 4, 16-30.

Tilong, A. D. (2012). Bebas dari ancaman kanker serviks. Yogyakarta: Flashbooks.

Wawan \& Dewi M, A. (2011). Teori \& pengukuran pengetahuan, sikap, dan perilaku manusia. Yogyakarta: Nuha Medika. 